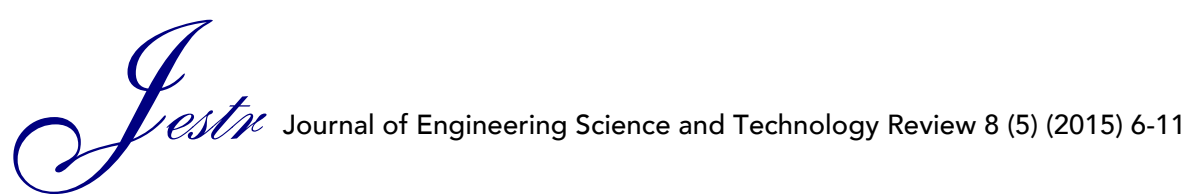

Research Article
JOURNAL OF

Engineering Science and

Technology Review

\title{
Study of a Wind/PV/Battery hybrid system - Case study at Plaka in Greece
}

www.jestr.org

\author{
J. G. Fantidis*, D. V. Bandekas and N. Vordos
}

Department of Electrical Engineering, Eastern Macedonia and Thrace Institute of Technology, Kavala, Greece

Received 10 September 2015; Accepted 15 December 2015

\begin{abstract}
The primary objective of this study is to determine the optimum hybrid system able to supply the necessary electrical load of a typical community in a remote location in Greece. The renewable energy systems were comprised of different combinations of PV modules and wind turbines supplemented with battery storage. A software tool, HOMER is used for the analysis. The hybrid system analysis has showed that the minimum cost of energy is $0.268 \$ / \mathrm{kWh}$ with $10 \%$ annual capacity of shortage. The optimum hybrid system is comprised of $1.5 \mathrm{~kW} \mathrm{PV}$ array, 1 wind generator, $3 \mathrm{~kW}$ power converter and 14 storage batteries.
\end{abstract}

Keywords: Hybrid Wind/PV/Battery system, Renewable energy, Net Present Cost (NPC)

\section{Introduction}

In remote areas, the cost of grid extension is prohibitive and the cost of fuels increases drastically with the remoteness of location. Renewable energy sources, such as photovoltaic, wind energy, or small-scale hydro, provide a realistic alternative to engine-driven generators for electricity generation [1]-[2]. The individual fluctuation of the wind and solar resources can be overcome using hybrid renewable energy systems with battery backup. Applications of hybrid systems vary from small power supplies for remote home providing electrical energy to village electrification for remote communities. There is adequate research work on hybrid energy systems [1-4].

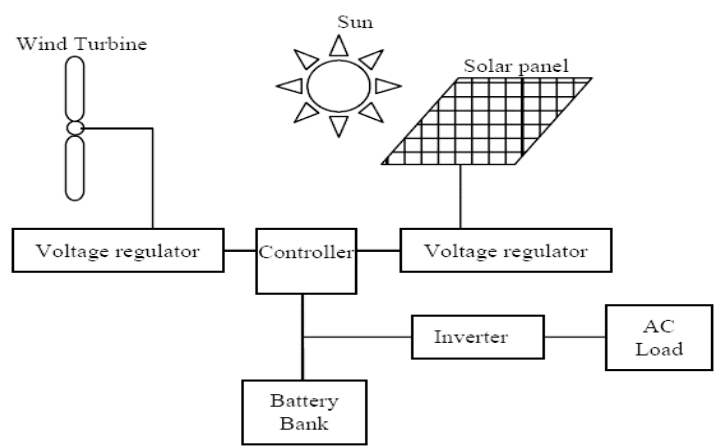

Fig. 1. Block diagram of a hybrid Wind/PV/Battery system

A basic schematic diagram of a hybrid Wind/PV energy system with battery storage is provided in Fig. 1. The system consists of PV generator, a wind generator, a battery

\footnotetext{
* E-mail address: fantidis@yahoo.gr
} ISSN: 1791-2377 @ 2015 Kavala Institute of Technology. All riahts reserved. storage system, a power converter able to meet the consumption peak load demand, charge controllers for wind turbine and PV modules to supply energy to the batteries at the appropriate voltage. As seen in Fig. 1, the battery bank stores energy when excess wind and solar energy is available and releases it for later lacking loads. The amount of the electricity produced via the system depends on the global solar radiation and the wind speed in general.

The Evros Prefecture is the northernmost of the prefectures of Greece. It is located in the eastern and northeastern part of the region of Thrace, and borders Turkey at the Evros River. Evros borders Bulgaria to the north and the northwest. The Rhodope prefecture borders it to the west. At the Rhodope sierra there is a small isolated village with name Plaka (see Fig. 2 from the Google maps) which is far from the power grid and consequently will not be connected to it. Taking advantage of the good solar and wind potential of Plaka (latitude $40^{\circ} 53 \mathrm{~N}$, longitude $25^{\circ} 43$ $\mathrm{E})$, a stand-alone hybrid Wind/PV system is proposed in order to meet the electricity demand of remote consumer.

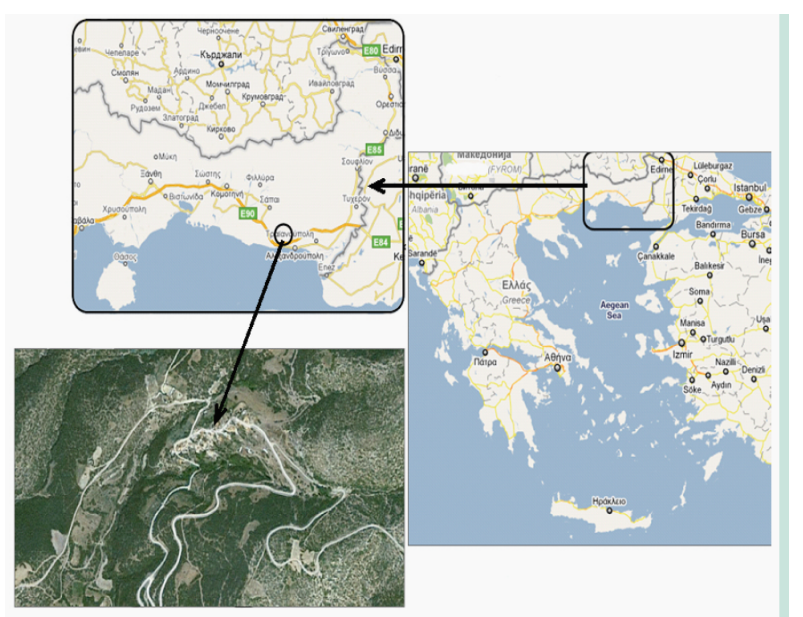

Fig. 2. Geographical location of the Plaka village 
The objective of this work is to presents the results of a feasibility analysis of using renewable energy systems (PV/Battery, Wind/Battery, hybrid PV/Wind/Battery) for electrification of a typical isolated rural household in Plaka. According to the fact that all areas in Greece have high irradiation level and the Plaka is situated in a mountain with high wind speeds, the necessary energy requirements may be obtained from renewable energy conversion systems such as wind turbines and PV panels. The overwhelming majority of the articles study the small or larger remote Greek islands; however, the present article is the first, which refers in the East Thrace (the most distant main land area in Greece). The area has one of the lowest standards of living in Greece.

Financial and economic crisis in Greece has changed the data on the field of the diesel price. On October 2009 the diesel price in Greece was approximately $0.8 € / \mathrm{L}$, however with rising fossil fuel prices and mainly with the new taxes today (December 2011) the diesel price costs more than $1.45 € / \mathrm{L}[5]$. Coinstantaneously new taxes and the slashing of salaries has changed the standard of living for many people in Greece, so the economic feasibility of diesel generators not only in the case study but in all Greece remote areas is debatable. In this paper, the present investigation carries out a detailed techno economic analysis simulations using HOMER (Hybrid Optimization Model for Electric Renewables) software [6]-[7]-[8]. HOMER is a modelling tool that facilitates design of standalone electric power systems. Many investigators have used Homer in order to find the optimum hybrid system [3]-[9]-[10]-[11]. Analysis with HOMER requires information on resources, control methods, energy storage medium and economic constraints. The assessment criterions of the analysis are the Cost of Energy (COE) and the Net Present Cost (NPC).

HOMER defines the levelled COE as the average $\operatorname{cost} / \mathrm{kWh}$ of useful electrical energy produced by the system. To calculate the COE, HOMER divides the annualized cost of producing electricity by the total useful electric energy production. The equation for the $\mathrm{COE}$ is as follows:

$$
C O E=C_{\text {ann }, \text { tot }} /\left(E_{\text {prim }, A C}+E_{\text {prim }, D C}+E_{\text {grid }, \text { sales }}\right)
$$

Where,

$C_{a n n, t o t}$ is the total annualized cost $(\$ / \mathrm{yr}), E_{\text {prim, } A C}$ is $\mathrm{AC}$ primary load served (kWh/year), $E_{\text {prim }, D C}$ is DC primary load served ( $\mathrm{kWh} /$ year), $E_{\text {grid,sales }}$ is total grid sales ( $\mathrm{kWh} /$ year).

HOMER is primarily an optimization software package, which simulates varied renewable energy sources system. HOMER displays a list of configurations; sorted by NPC is the present value of all the costs that it incurs over its lifetime, minus the present value of all the revenue that it earns over its lifetime. HOMER calculates the total NPC using the following equation [12]:

$$
C_{N P C}=C_{\text {ann,tot }} / C R F\left(i, R_{\text {proj }}\right)
$$

where $C R F$ is the capital recovery factor, $i$ the interest rate (\%) and $R_{\text {proj }}$ the project lifetime (yr). The $C R F$ is given by the following equation

$$
C R F=i(i+1)^{R_{\text {proj }}} /\left[(i+1)^{R_{\text {proj }}}-1\right]
$$

\section{Meteorological Data}

In order to calculate the performance of a hybrid Wind/PV system it is necessary to collect the meteorological data for the site location under consideration. The CRES (Centre for Renewable Energy Sources and Saving) is a source for these data [13]. CRES is the Greek national entity for the promotion of renewable energy sources, rational use of energy and energy conservation.

The annual energy generated from wind turbines $W_{\text {elec }}$, is given by the equation

$W_{\text {elec }}=\sum_{t=1}^{N_{h}} N_{t r} P_{t r}\left(v_{t}\right)$

where $t$ is the hour of the year, $N_{t r}$ the number of turbines at the site, $P_{t r}$ the power output as function of the average wind speed over a given hour, and $N_{h}$ the number of data hour in the year [14]. The wind power output is given by the following relationship:

$\mathrm{P}_{\mathrm{w}}=\mathrm{n}_{\mathrm{t}} \times \mathrm{n}_{\mathrm{g}} \times 0.5 \times \mathrm{p}_{\alpha} \times \mathrm{C}_{\mathrm{p}} \times \mathrm{A} \times \mathrm{V}_{\mathrm{r}}^{3}$

where :

$\mathrm{V}_{\mathrm{r}}$ the wind velocity,

$\mathrm{p}_{\mathrm{a}}$ the air density,

$\mathrm{C}_{\mathrm{p}}$ the power coefficient of wind turbine,

A the wind turbine rotor swept area and

$n_{t} \& n_{g}$ are the wind turbine and generator efficiency, respectively

as obtained from the manufacturers' data.

The monthly average wind speeds for the period 19512001 are presented in Fig. 3a. Generally, the cut-in wind speed of most of the wind generators ranges from 3 to $4 \mathrm{~m} / \mathrm{s}$. The wind duration analysis points to that the wind speeds are more than $3 \mathrm{~m} / \mathrm{s}$ for about $85.2 \%$ and more than $4 \mathrm{~m} / \mathrm{s}$ for about $75 \%$ (at $10 \mathrm{~m}$ height) of the time during the year. As it can be seen, wind speeds are generally higher during the months November to March as compared to other months. This indicates that a wind generator produce more energy during winter. Notably, the data also shows that there is a considerable variation of the monthly average wind speed during summer.
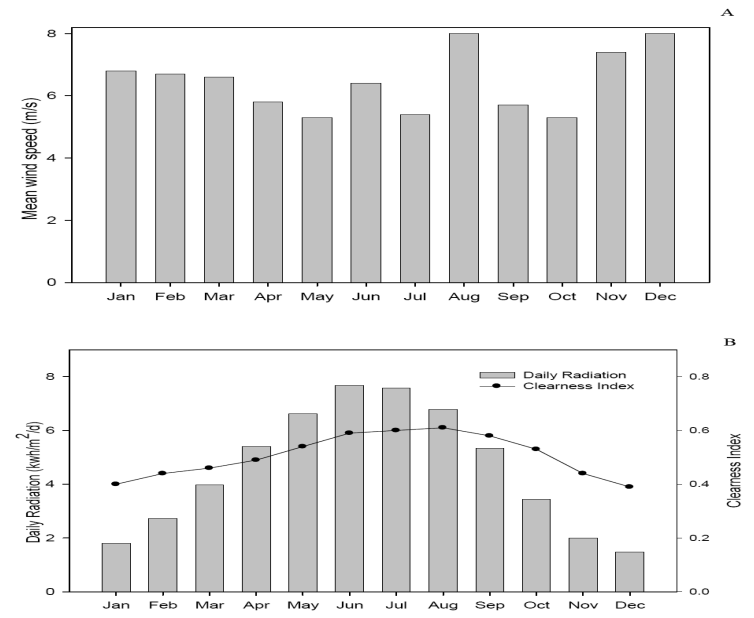

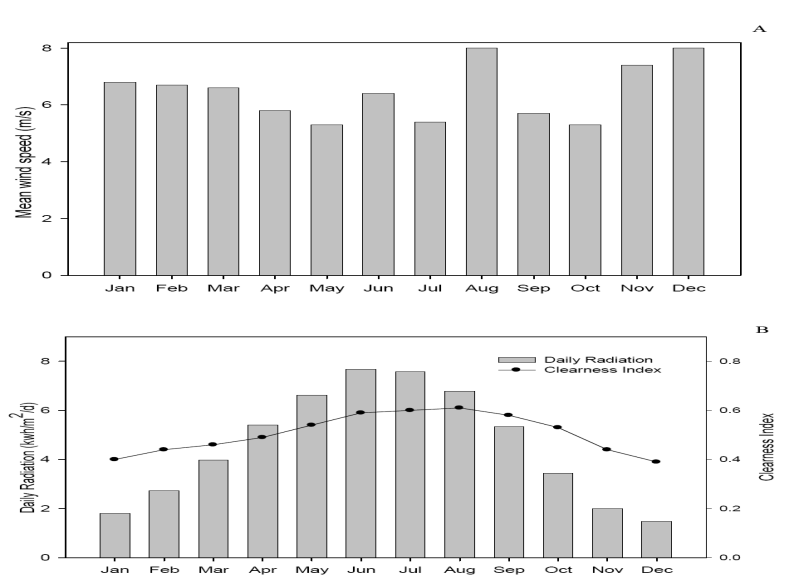

Fig. 3. Monthly average wind speeds (a), monthly variation of global radiation and monthly average daily clearness index (b)at Plaka locations

The annual output power of the PV generator $\mathrm{S}_{\text {elec }}$ can be calculated by the equation

$S_{\text {elec }}=\sum_{t=1}^{N_{h}} n_{\text {solar }, t} A_{\text {solar }} G_{t}$

where $G_{t}$ is the hourly insulation in $\mathrm{Wm}^{-2}, A_{\text {solar }}$ the fixed area of the solar field and $n_{\text {solar, }}$ the solar conversion efficiency for a given hour of day during a given month [14]. If we choose that the effect of temperature on the PV is negligible HOMER uses the following equation to calculate the output of the PV array:

$P_{P V}=Y_{P V} f_{P V} \overline{\mathrm{G}}_{\mathrm{T}} / \overline{\mathrm{G}}_{\mathrm{T}, \mathrm{STC}}$

where $\mathrm{Y}_{\mathrm{PV}}$ is the rated capacity of the PV array, meaning its power output under standard test conditions $[\mathrm{kW}], \mathrm{f}_{\mathrm{PV}}$ the $\mathrm{PV}$ derating factor [\%], $\overline{\mathrm{G}}_{\mathrm{T}}$ the solar radiation incident on the PV array in the current time step $\left[\mathrm{kW} / \mathrm{m}^{2}\right]$ and $\overline{\mathrm{G}}_{\mathrm{T}, \mathrm{STC}}$ the incident radiation at standard test conditions $\left[1 \mathrm{~kW} / \mathrm{m}^{2}\right]$. The total annual electrical output of the hybrid system can then be calculated as the sum of $S_{\text {elec }}$ and the $W_{\text {elec }}$ values.

The monthly mean values of the global solar radiation (GSR) are shown in Fig. 3b. It represents the monthly average daily GSR and monthly average daily clearness index. The case study area has special concern because of excellent wind potential, comparable with the famous Greek islands but less solar radiation. There are many other similar places in Greece like Epirus and East Macedonia, which have excellent wind potential but the solar potential is $25 \%$ less than the Aegean Archipelagos islands. Since measured hourly solar radiation data is rarely available, it is often necessary to use HOMER's capability to generate synthetic hourly solar data from monthly averages. The algorithm that HOMER uses to synthesize solar data is based on the work of V. A. Graham and Hollands [15]. This algorithm produces realistic hourly data and it is easy to use due to the fact that it requires only the latitude and the monthly averages.

It is clear from the Fig. $3 \mathrm{~b}$ that solar energy incident in the considered site is very high during the summer months. The average daily global radiation for Plaka region is 4.6 $\mathrm{kWh} / \mathrm{m}^{2}$ per day. The highest values of GSR are observed during the months of June to August with a maximum of
$7.68 \mathrm{kWh} / \mathrm{m}^{2}$ per day. Lower values of GSR are observed during the months from November to January.

\section{Load and Energy Characteristics of the Region}

Table 1. Average Monthly Energy Demand Of Typical Household On Plaka

\begin{tabular}{c|ccc}
\hline \multirow{2}{*}{ Appliance } & \multicolumn{3}{|c}{$\begin{array}{c}\text { Daily energy consumption per } \\
\text { appliance (kWh) }\end{array}$} \\
\cline { 2 - 4 } & Winter & $\begin{array}{c}\text { Spring - } \\
\text { Autumn }\end{array}$ & Summer \\
\hline $\begin{array}{c}\text { Food freezer } \\
\text { Refrigerator-freezer }\end{array}$ & 1.35 & 1.89 & 2.7 \\
Washing machine & 3 & 3.5 & 4 \\
Dishwasher & 0.25 & 0.25 & 0.25 \\
Tv & 1 & 1 & 1 \\
Lighting & 0.3 & 0.3 & 0.3 \\
Other & 1 & 0.7 & 0.4 \\
Cook & 0.75 & 0.75 & 0.75 \\
Heater & 3 & 3 & 3 \\
Total daily energy & 4.5 & 4 & 4 \\
consumption & 15.15 & 15.39 & 15.4 \\
Annual energy & & & \\
consumption per & & 5519.7 & \\
household. & & & \\
\hline
\end{tabular}

The load characteristic is critically important to the system optimization. The total daily consumption of a typical household is in the region of $15.15-15.4 \mathrm{kWh}$ (see Table 1) [16]. Unfortunately measured hourly load information over the year in Plaka was not available and the size and shape of load profile fluctuate from hour to hour and from day to day. For this reason, on a daily and hourly basis a $15 \%$ noise level has been added to the calculated load with the purpose of randomize the load profile and make it more realistic. This has magnified the annual peak load to $5.1 \mathrm{~kW}$.

\subsection{The proposed autonomous hybrid Wind/PV/Battery system}

Table 2. Components Of The Hybrid System Analysis

\begin{tabular}{|c|c|c|c|c|}
\hline $\begin{array}{c}\text { Characteristi } \\
\text { cs } \\
\end{array}$ & $\begin{array}{c}\text { PV } \\
\text { module }\end{array}$ & $\begin{array}{c}\text { Wind } \\
\text { turbine }\end{array}$ & Battery & Converter \\
\hline Model & Typical & $\begin{array}{l}\text { WES } 5 \\
\text { Tulipo }\end{array}$ & $\begin{array}{c}\text { Trojan T- } \\
105\end{array}$ & Typical \\
\hline Power & $1 \mathrm{~kW}$ & $3 \mathrm{~kW}$ & $\begin{array}{c}\text { Nominal } \\
\text { voltage: } \\
6 \mathrm{~V} \\
\text { nominal } \\
\text { capacity:2 } \\
25 \mathrm{Ah} \\
(1.35 \mathrm{kWh} \\
)\end{array}$ & $1 \mathrm{~kW}$ \\
\hline Life time & 25 year & 15 year & $\begin{array}{l}\text { Lifetime } \\
\text { throughpu } \\
\text { t } 845 \mathrm{kWh}\end{array}$ & 25 year \\
\hline Price & $\begin{array}{c}4000 \$ / \mathrm{k} \\
\mathrm{Wp}\end{array}$ & $\begin{array}{l}5000 \$ / \text { tur } \\
\text { bine }\end{array}$ & $\begin{array}{c}128 \$ / \text { batte } \\
\text { ry }\end{array}$ & $400 \$ / \mathrm{kW}$ \\
\hline Replacement & $\begin{array}{c}4000 \$ / \mathrm{k} \\
\mathrm{Wp}\end{array}$ & $\begin{array}{l}4000 \$ / \text { tur } \\
\text { bine }\end{array}$ & $\begin{array}{c}115 \$ / \text { batte } \\
\text { ry }\end{array}$ & $250 \$ / \mathrm{kW}$ \\
\hline Maintenance & $3 \$ / \mathrm{kW}$ & $\begin{array}{c}50 \$ / \text { turbin } \\
\mathrm{e}\end{array}$ & $1 \$ /$ battery & $1 \$ / \mathrm{kW}$ \\
\hline
\end{tabular}

The initial capital, operation and maintenance (O\&M) costs of PV modules were determined based on the current prices of PV modules in Greece and are depicted in Table II. The derating factor was taken as 0.9 and PV panels are mounted at a fixed slope and azimuth. WES 5 Tulipo wind turbine is considered with rated power of $3 \mathrm{~kW}$, has $5 \mathrm{~m}$ 
rotor diameter and $6.25 \mathrm{~m}$ of tower. The power curve of a WES 5 Tulipo wind turbine is shown in Fig. 4 [17].

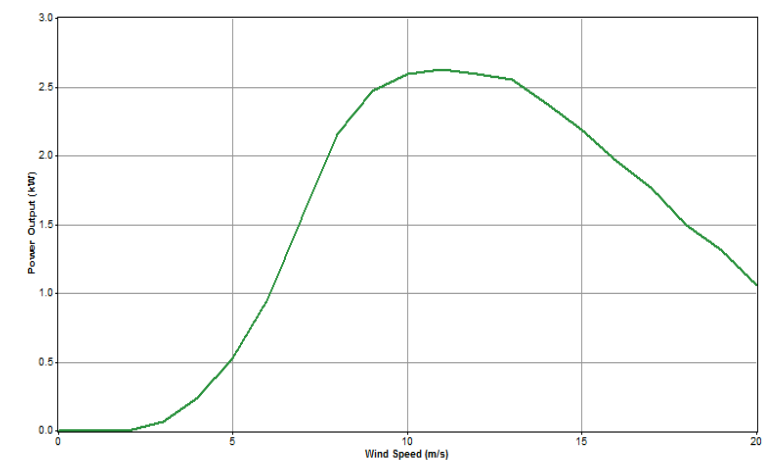

Fig. 4. Wind power curve of the WES 5 Tulipo wind turbine

The battery capacity and type were chosen from batteries specified in HOMER, Trojan T-105 [18] is considered in the models. The function of the power converter is to maintain the flow of energy between the AC and DC components. Different sizes of converter $(\mathrm{kW})$ were used in the present study and the lifetime of a unit was considered to be $25 \mathrm{yr}$ with an efficiency of $90 \%$. The characteristics and the cost data of the wind machine, batteries and power converter considered in this study are also depicted in Table II [19]-[20]-[21]-[22].

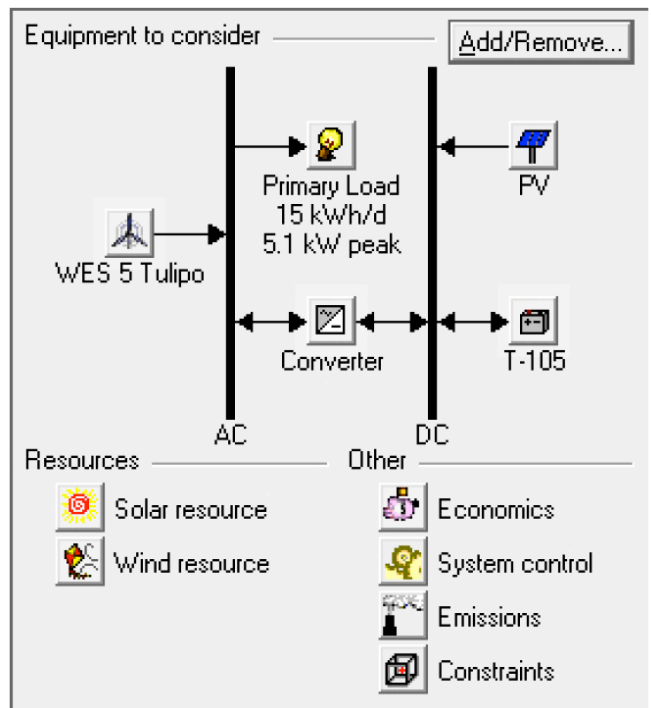

Fig. 5. HOMER diagram for the hybrid Wind/PV generator/Battery/converter setup

The proposed hybrid Wind/PV/Battery system consists of wind turbines, solar PV array, battery bank and power converter. Its schematic diagram is shown in Fig. 5.

The system control parameters used in this investigation are summarized in Table III. The project life time has been considered to be $25 \mathrm{yr}$ and the annual real interest rate has been taken as $6 \%$.

Table 3. Constraints Used In Software Spinning Reserve Inputs In Software

\begin{tabular}{c|c}
\hline Parameters & Value \\
\hline Minimum battery life & N/A \\
Maximum annual capacity shortage & $10 \%$ \\
Percent of annual peak load & $0 \%$ \\
Percent of hourly load & $5 \%$ \\
Percent of hourly solar output & $50 \%$ \\
Percent of hourly wind output & $50 \%$ \\
\hline
\end{tabular}

\section{Results and discussion}

\subsection{PV/Battery system}

In this system, PV panels supply entire load. The most feasible PV/Battery system comprised of $6 \mathrm{~kW} \mathrm{PV}$ arrays, $54 \mathrm{kWh}$ storage batteries in addition to $4 \mathrm{~kW}$ converter. According to the HOMER calculations the PV panels produces $10176 \mathrm{kWh} / \mathrm{yr}$. NPC of the system is found as $36607 \$$ and $0.559 \$ / \mathrm{kWh}$ is the COE (see Table IV).

Table 4. The Comparisons Among the Optimized Hibrid Options

\begin{tabular}{|c|c|c|c|c|c|c|c|c|}
\hline $\begin{array}{l}\text { Opti } \\
\text { ons }\end{array}$ & $\begin{array}{l}\text { PV } \\
\text { (k } \\
\text { W) }\end{array}$ & $\begin{array}{l}\text { WE } \\
\text { S 5 } \\
\text { Tul } \\
\text { ipo }\end{array}$ & $\begin{array}{c}\text { Batt } \\
\text { ery } \\
\text { troj } \\
\text { an } \\
T- \\
105\end{array}$ & $\begin{array}{l}\text { Conv } \\
\text { erter } \\
\text { kW }\end{array}$ & $\begin{array}{l}\text { Init } \\
\text { ial } \\
\text { capi } \\
\text { tal } \\
\text { (\$) }\end{array}$ & $\begin{array}{c}\text { Oper } \\
\text { ating } \\
\text { cost } \\
\text { (\$/yea } \\
\text { r) }\end{array}$ & $\begin{array}{c}\text { Tot } \\
\text { al } \\
\text { NP } \\
\text { C } \\
\text { (\$) }\end{array}$ & 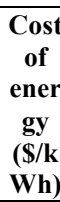 \\
\hline $\begin{array}{l}\frac{1}{2} \\
\frac{1}{1} \\
\frac{1}{3} \\
\vdots \\
\vdots \\
\vdots\end{array}$ & 1.5 & 1 & 14 & 3 & $\begin{array}{c}139 \\
92\end{array}$ & 304 & $\begin{array}{c}178 \\
79\end{array}$ & $\begin{array}{c}0.26 \\
8\end{array}$ \\
\hline 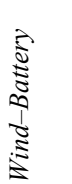 & & 2 & 18 & 3 & $\begin{array}{c}135 \\
04\end{array}$ & 453 & $\begin{array}{c}193 \\
01\end{array}$ & $\begin{array}{c}0.29 \\
2\end{array}$ \\
\hline 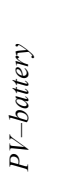 & 6 & & 40 & 4 & $\begin{array}{c}307 \\
20\end{array}$ & 460 & $\begin{array}{c}366 \\
07\end{array}$ & $\begin{array}{c}0.55 \\
9\end{array}$ \\
\hline
\end{tabular}

As mentioned previously, the monthly average of solar radiation at Plaka is high during summer months as compared to the other months. This means that the PV panels produce more power in summer and lower the other months especially during the months from November to January.

\subsection{Wind/Battery system}

In this case, the optimum Wind/Battery composed of 2 WES 5 Tulipo wind turbines, $24.3 \mathrm{kWh}$ storage batteries and 3 $\mathrm{kW}$ of power converter. This system uses $100 \%$ renewable energy comes from wind turbine $(19358 \mathrm{kWh} / \mathrm{yr})$. A comparison between the best Wind/Battery and PV/Battery (see Table IV) systems shows that the first has about the half NPC and COE (19301 \$ and $0.292 \quad \$ / \mathrm{kWh}$, respectively). The wind turbines power output daily profile at Plaka presents significant fluctuation owing to the considerable variation of the monthly average wind speed.

\subsection{Wind/PV/Battery system}

Numerous simulations for various scenarios have been made by considering different combinations of wind generators and PV panels with hybrid systems. Based on the HOMER modelling, the optimal system for a typical household in Plaka is a hybrid Wind/PV/Battery system, with $1.5 \mathrm{~kW}$ of solar, a $3 \mathrm{~kW}$ wind generator, $18.9 \mathrm{kWh}$ of batteries and 3 $\mathrm{kW}$ of power converter. This "optimal" system uses $100 \%$ renewable energy in which $79 \%$ electricity comes from wind source $(9679 \mathrm{kWh} / \mathrm{yr})$ and $21 \%$ electricity comes from solar radiation (2544 kWh/yr) with an annual capacity of shortage $10 \%$. It is revealed that wind energy is advantageous in Plaka. The annual electricity production 
from the optimal hybrid system is $12223 \mathrm{kWh}$. There are no $\mathrm{CO}_{2}$ and $\mathrm{SO}_{2}$ emissions as there is no diesel generator. The comparison among the optimized Wind/PV/Battery system with Wind/Battery and PV/Battery system is given in Table IV. The optimization results show that the optimal Wind/PV/Battery system has lowest NPC (17879 \$) with COE $0.268 \$ / \mathrm{kW}$. From the Table IV it is clear that the optimized Wind/PV/Battery system reduces the COE about $7 \%$ and $51 \%$ compared with Wind/Battery and PV/Battery respectively. The total costs of each component are shown in Fig. 6a. Fig. 6b shows the average monthly electrical production.
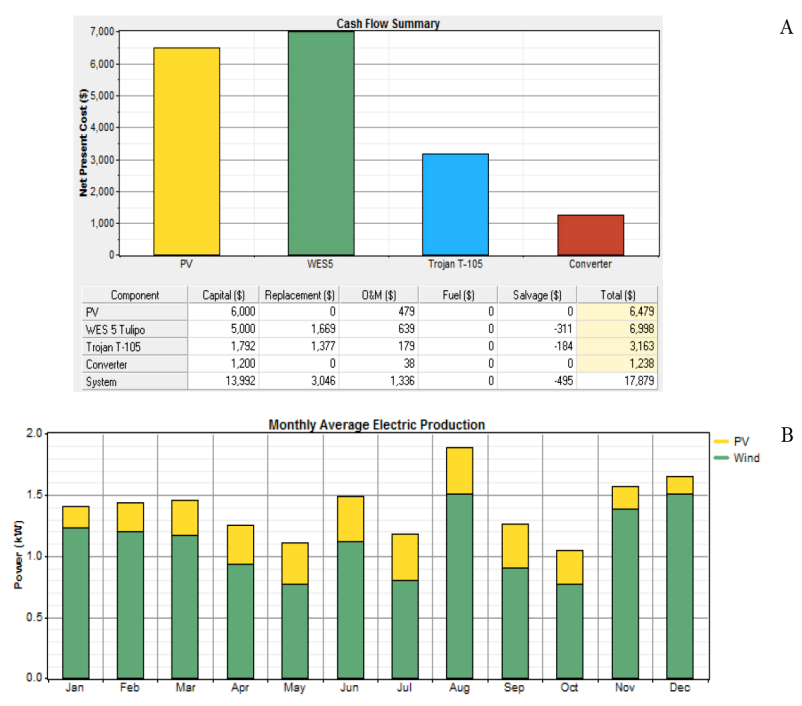

Fig. 6. Cash flow summary of the optimized Wind/PV/Battery hybrid system (a) and monthly mean power contribution (b)

In order to give a general overview of the situation, the results obtained from the sensitivity analysis in the form of a sensitivity graph [22]. Fig. 7 exhibits the sensitivity analysis in term of wind speed and the global solar irradiation.

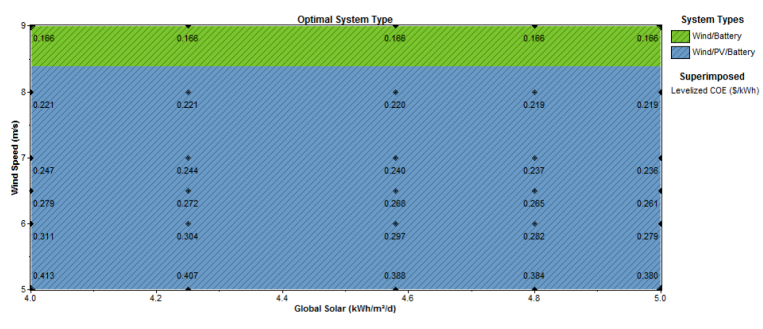

Fig. 7. Sensitivity of Wind Speed to Global Solar Radiation for Plaka

In the present case, wind speed $(5,6,6.5,7,8$ and $9 \mathrm{~m} / \mathrm{s})$ and GSR $\left(4,4.25,4.58,4.8\right.$ and $5 \mathrm{kWh} / \mathrm{m}^{2}$ per day) were used as sensitivity variables. In winds above $8.45 \mathrm{~m} / \mathrm{s} \mathrm{PV}$ is eliminated from the system. However, the Wind/PV/Battery system becomes competitive below $8.45 \mathrm{~m} / \mathrm{s}$.

\section{Conclusion}

In the present study, a techno-economic feasibility of standalone renewable energy systems to meet the electricity requirements of a typical remote village of Greece was investigated. HOMER was used for the analysis and viability was determined based on NPC and COE. From this study, it is clear that the optimized Wind/PV/Battery hybrid system is more cost effective compared to Wind/Battery or $\mathrm{PV} /$ Battery systems for the load with $10 \%$ annual capacity of shortage. Wind and solar energy resources at Plaka have showed that an optimized Wind/PV/Battery can serve a typical remote settlement electricity demand with COE of $0.268 \$ / \mathrm{kWh}$. Generally, the results from the sensitivity analysis showed that the maximum electricity comes from wind, which predicts that wind is more feasible than the solar at the site. In such system $21 \%$ electricity comes from solar resource and $79 \%$ electricity comes from wind resource, the hybrid of the two energy resources reduces the $\mathrm{COE}$ of $7 \%$ and $51 \%$, respectively, in comparison with Wind/Battery and PV/Battery combinations. The monthly average electricity production of the most feasible hybrid system showed that higher electricity production is noticed during the winter months (November-December) and on August as compared to other months.

\section{References}

1. S. K. Nandi and H. R. Ghosh, A wind-PV-battery hybrid power system at Sitakunda in Bangladesh, Energy Policy, vol. 37, 2009, pp. 3659-3664.

2. S. S. Dihrab and K. Sopian, Electricity generation of hybrid PV/wind systems in Iraq, Renewable Energy, vol. 35, 2010, pp. 1303-1307.

3. P. Balamurugana, S. Ashok and T. L. Jose, An Optimal Hybrid Wind-biomass Gasifier System for Rural Areas, En. Sources A, vol. 33, 2011, pp. 823-832.

4. A. H. Al-Badi, M. AL-Toobi, S. AL-Harthy, Z. Al-Hosni and A. AL-Harthy, Hybrid systems for decentralized power generation in Oman, Int. J. of Sust. Energy, vol. iFirst 1-11, 2011.

5. Hellenic ministry of development (http://www.ypeka.gr).

6. HOMER Publications, NationalRenewable Energy Laboratory available https://analysis.nrel.gov/homer/includes/downloads/HOMERPublic ations.pdf

7. J.G.Fantidis, D.V.Bandekas, C.Potolias, N.Vordos, " The Effect of the Financial Crisis On Electricity Cost For Remote Consumers: Case Study Samothrace (Greece)', International Journal of Renewable Energy Research, IJRER, Vol.1, No.4, pp.281-289, 2011.
8. J.G.Fantidis, D.V.Bandekas, C.Potolias, N.Vordos, Cost of PV Electricity - Case study of Greece, Solar Energy, Vol.91, pp.120130,2013

9. A. H. Al-Badi and H. Bourdoucen, Study and design of hybrid diesel-wind standalone system for remote area in Oman, Int. J. of Sust. Energy, 2011, DOI:10.1080/1478646X.2011.554608.

10. I. Baniasad Askari and M. Ameri, Techno-economic Feasibility Analysis of Stand-alone Renewable Energy Systems (PV/bat, Wind/bat and Hybrid PV/wind/bat) in Kerman, Iran, Energy S. B: Econ., Plan and Pol., vol. 7, n.1, 2012, pp. 45-60

11. K. Karakoulidis, K. Mavridis, D. V. Bandekas, P. Adoniadis, C. Potolias and N. Vordos, Techno-economic analysis of a standalone hybrid photovoltaic-diesel-battery- fuel cell power system, Renewable Energy, 2011, pp.1-7.

12. NREL (National Renewable Energy Laboratory), 2011, HOMER Computer Software, Version 2.68 beta, Retrieved from https://analysis.nrel.gov/homer/S

13. http://www.cres.gr

14. J. P. Reichling and F. A. Kulacki, Utility scale hybrid wind-solar thermal electrical generation: A case study for Minnesota, Energy, vol. 33, 2008, pp. 626-638.

15. V. A. Graham and K. G. T. Hollands, A method to generate hourly solar irradiation, globally, Solar Energy, vol. 44, n. 6, 1990, pp. 
333-341.

16. V. Mantzari, Renewable energy resources/Study of installation a wind/hydro power system in Alexandroupoli area, MSc Thessis, NTUA, Dept. of Civil Engineering, Athens, 2009.

17. http://www.windenergysolutions.nl/

18. http://www.trojan-battery.com

19. E. S. Hrayshat, Techno-economic analysis of autonomous hybrid photovoltaic-diesel-battery system, En. for Sustain Develop. vol. 13, 2009, pp. 143-150.

20. S. K. Nandi and H. R. Ghosh, Prospect of wind-PV-battery hybrid power system as an alternative to grid extension in Bangladesh, Energy, vol. 35, 2010, pp. 3040-3047.
21. A. Demiroren, and U. Yilmaz, Analysis of change in electric energy cost with using renewable energy sources in Gökceada, Turkey: An island example, Ren. and Sust, Energy Reviews, vol. 14, 2010, pp. 323-333.

22. B. E. Türkay and A. Y. Telli, Economic analysis of standalone and grid connected hybrid energy systems, Renewable Energy, vol. 36, 2011, pp. 1931-1943. 